\title{
Impact of Drip Fertigation on Yield and Nutrients Uptake by Chilli (Capsicum annuum L.)
}

\author{
Ajeet Singh $^{1 *}$, S.K. Sharma ${ }^{1}$, Rahul Chopra ${ }^{1}$, Virendra Singh ${ }^{2}$, \\ R.A. Kaushik ${ }^{2}$, R.S. Rathore ${ }^{3}$ and H.K. Jain ${ }^{4}$ \\ ${ }^{1}$ Department of Agricultural Chemistry and Soil Science, RCA, MPUAT, \\ Udaipur, Rajasthan 313001, India \\ ${ }^{2}$ Department of Horticulture, RCA, MPUAT, Udaipur, Rajasthan 313001, India \\ ${ }^{3}$ Department of Extension, RCA, MPUAT, Udaipur, Rajasthan 313001, India \\ ${ }^{4}$ Department of Agricultural Statistics and Computer Application, RCA, MPUAT, \\ Udaipur, Rajasthan 313001, India \\ *Corresponding author
}

\begin{tabular}{|c|c|}
\hline & A B S T R A C T \\
\hline & \multirow{5}{*}{ 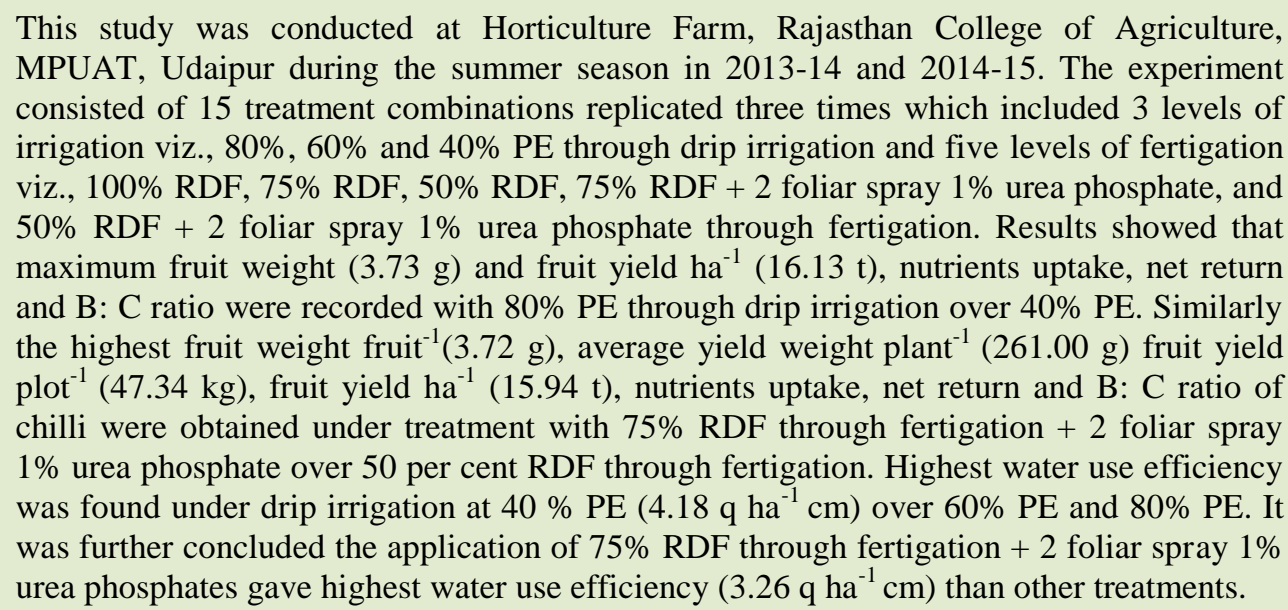 } \\
\hline Keywords & \\
\hline $\begin{array}{l}\text { Fetigation, yield, } \\
\text { nutrient uptake, } \\
\text { water efficiency, } \\
\text { economics and } \\
\text { chilli. }\end{array}$ & \\
\hline Article Info & \\
\hline $\begin{array}{l}\text { Accepted: } \\
\text { 17 June } 2017 \\
\text { Available Online: } \\
10 \text { August } 2017\end{array}$ & \\
\hline
\end{tabular}

\section{Introduction}

Water and nutrient management are the key factors for successful cultivation of vegetable crops, which responds well to nutrient and irrigation regime. In crop intensive agriculture, both irrigation and fertilizer management have contributed immensely in increasing the yield and quality of crops. Water plays vital role in improving plant growth and crop production; it is the most limiting factor in Indian agricultural scenario. In India, the potential for the drip irrigation system is estimated to be $21.27 \mathrm{mha}$ (Narayanamoorthy, 2008). Water saving from drip irrigation system varied from 12 to $84 \%$ for different crops besides increasing the production of crops. Due to water scarcity, the available water resources should be very effectively utilized through water saving 
irrigation technologies. The need of the hour is, therefore, to maximize the production unit1 of water. Hence, further expansion of irrigation may depend upon the adoption of new systems such as pressurized irrigation methods with the limited water resources. Amongst those pressurized irrigation methods, drip irrigation has proved its superiority over other methods of irrigation due to the direct application of water and nutrients in the vicinity of root zone. Drip irrigation is the concept where water is applied at low rate frequently near the root zone of the plant. Drip irrigation system can be easily used for fertigation through which the applied fertilizer is placed to the active root zone and crop nutrient requirement can be met accurately (Neilsen et al., 2004). The reason why fertigation has become the state of art in plant nutrition particularly in arid environments is that nutrients can be applied in the correct dosage and at the required time appropriate for each specific growth stage. Fertilizers applied under conventional methods of irrigation are generally not efficiently used by the crop (Hebbar et al., 2004). Proper fertigation management requires the knowledge of soil fertility status and nutrient uptake pattern of the crop. Monitoring of soil and plant nutrient status is an essential safeguard to ensure maximum crop productivity. Since, fertigation enhances the fertilizer use efficiency owing to the frequent application of fertilizer directly into the soil where root activity tends to be concentrated and hence reduction in fertilizer rate is possible without compromising the yield of crop.

Chilli (Capsicum annuum L.) is one of the most popular and high value vegetable crops grown for its immature fruits throughout the world. Chilli consumption in India has increased now- a- days due to increased demand by urban consumers. The nutritive value of chilli is excellent. It is also rich sources of vitamins, especially in A, B and C. India has produced about 65.9 thousand tonnes of Chilli with area of 7.7 thousand hectares and productivity 8.61 tonnes per hectares (Vegetable Statistics, 2013-14). Taking into account the above facts a field experiment was conducted to find out the effect of irrigation and fertigation levels on yield parameters, nutrients uptake, water use efficiency and economic of chilli (Capsicum annuит $\mathrm{L}$.).

\section{Materials and Methods}

The experiment was conducted at Horticulture Farm, Rajasthan College of Agriculture, MPUAT, Udaipur during summer season in 2013-14 and 2014-15. The soil was Haplustepts, clay loam in texture having $\mathrm{pH}$ 8.15, EC $0.67 \mathrm{dS} \mathrm{m}^{-1}$, Organic carbon $0.71 \%$, available nitrogen $296.45 \mathrm{~kg} \mathrm{ha}^{-1}$, available phosphorus $23.76 \mathrm{~kg} \mathrm{ha}^{-1}$ and available potassium $318.65 \mathrm{~kg} \mathrm{ha}^{-1}$. The experiment was laid out in split plot design with 15 treatment combinations which consisted of 3 levels of drip irrigation $(80 \%, 60 \%$ and $40 \%$ $\mathrm{PE})$ and 5 levels of fertigation $(100 \% \mathrm{RDF}$, 75\% RDF, 50\% RDF, 75\% RDF + 2 foliar spray $1 \%$ urea phosphate, and 50\% RDF +2 foliar spray $1 \%$ urea phosphate through fertigation) were replicated three times. Four weekes old seedling of chilli variety Pusa Jwala was transplanted in last week of March and harvested in the last week of June. The water soluble fertilizers (urea, urea phosphate and potassium nitrate) were used in experiment through drip irrigation. The fertilizers were applied at fifteen days interval in 6 equal splits starting from 15 days after transplanting through drip irrigation according to fertilizer schedules. The fertilizer schedules was developed according to RDF (70-40-50 NPK kg ha ${ }^{-1}$ ) for chilli crop. In drip irrigation scheduling was done based on pan evaporation and application of water three days interval according to requirement of the 
crop. In order to determine the optimum water requirement for crops, three irrigation levels were adopted with 80,60 and 40 percent $(\mathrm{PE})$ water requirement of the crop. The discharge rate of the emitter was 4 liters per hour at nominal pressure of $1.5 \mathrm{~kg} \mathrm{~cm}^{-2}$. The yield of fruits per hectare was calculated by multiplying the average yield of fruits per sq. meter and expressed in tan per hectare.

Uptake of macro $(\mathrm{N}, \mathrm{P}, \mathrm{K})$ were computed from the data of $\mathrm{N}, \mathrm{P}$ and $\mathrm{K}$ content in fruit and plant by using the following formula

Nutrient uptake

(\% nutrient content in fruit) $\mathrm{x}$ \{fruit yield $\left.\left(\mathrm{kg} \mathrm{ha}^{-1}\right)\right\}$

In fruit $\left(\mathrm{kg} \mathrm{ha}^{-1}\right)=$

100

Nutrient uptake

(\% nutrient content in plant) $\mathrm{x}$ \{plant yield $\left.\left(\mathrm{kg} \mathrm{ha}^{-1}\right)\right\}$

In plant $\left(\mathrm{kg} \mathrm{ha}^{-1}\right)=$

100

The water use efficiency was computed by dividing yield $\left(\mathrm{q} \mathrm{ha}{ }^{-1}\right.$ ) with total water applied (cm) including effective rainfall.

$$
\text { WUE }(q / h a-c m)=\frac{\text { Yield }(\mathrm{kg} / \mathrm{ha})}{\text { Total water applied }(\mathrm{cm})}
$$

\section{Results and Discussion}

\section{Yield and yield attributed}

Yield and yield attributed of chilli as influenced by different levels of drip irrigation and fertigation are presented in Table 1 and Fig.2. A perusal of data indicated that the highest yield attributes viz., fruit weight per fruit $(3.73 \mathrm{~g})$ and fruit yield $\mathrm{ha}^{-1}$ $(16.14 \mathrm{t})$, respectively were observed in the drip irrigation at $80 \% \mathrm{PE}$ over $40 \% \mathrm{PE}$. The increase in yield might be due to better proportion of air-soil water which was maintained throughout the life period of crop in drip irrigation as reported by Kadam and Karthikeyan (2006). The increase in chilli yield under drip irrigation system may be due to the availability of water all the time when needed around the root zone at very low moisture tension. Singh and Kumar (2007) also reported the maximum fruit weight and tomato yield with $80 \%$ ET. Similar findings are also reported by Gupta and Chattoo (2014).

Data further revealed that the highest fruit weight fruit ${ }^{-1}(3.72 \mathrm{~g})$ and fruit yield $\mathrm{ha}^{-1}$ (159.39 t), respectively were obtained by application of $75 \%$ RDF through fertigation + 2 foliar spray of $1 \%$ urea phosphate which was significant superior than other treatments on the pooled basis (Table 1 and Fig.2). The important reasons responsible for better production of yield and yield attributes might be $75 \%$ RDF due to better performance under drip fertigation as compared to conventional method of fertilizer application can be attributed to maintenance of favourable nutrient-water interaction in the root zone, which in turn might have helped the plant to utilige nutrients more efficiently. These results are in agreement with the findings of several researchers in different vegetable crops such as Kadam et al., (2006) and Vjekoslav et al., (2010) and Ayyadurai and Manickasundaram (2014).

\section{Nutrient uptake}

$\mathrm{N}, \mathrm{P}$ and $\mathrm{K}$ uptake of chilli crop as influenced by different levels of drip irrigation and fertigation are presented in Table 2. Results showed that increasing the levels of drip irrigation significantly increased $\mathrm{N}, \mathrm{P}$ and $\mathrm{K}$ uptake by chilli. Data on pooled basis showed that the highest nitrogen (94.91 kg ha-1), phosphorus $\left(20.11 \mathrm{~kg} \mathrm{ha}^{-1}\right)$ and potassium (140.29 $\left.\mathrm{kg} \mathrm{ha}^{-1}\right)$ uptake in chilli were observed under application of drip irrigation 
at $80 \%$ PE over drip irrigation at $40 \%$ PE. Drip irrigation (80\% PE) increase the nutrient uptake, it may be due to approaching towards meeting the daily evaporation demand through drip irrigation, increased the availability of moisture resulting in higher nutrient uptake through its influence on biomass production and on the availability of nutrients. Preferential uptake of water from the sufficiently moist soil promoted the movement of nutrient ions towards roots and their uptake (Sanchez et al., 2001).

Fig.1 Experiment site of chilli
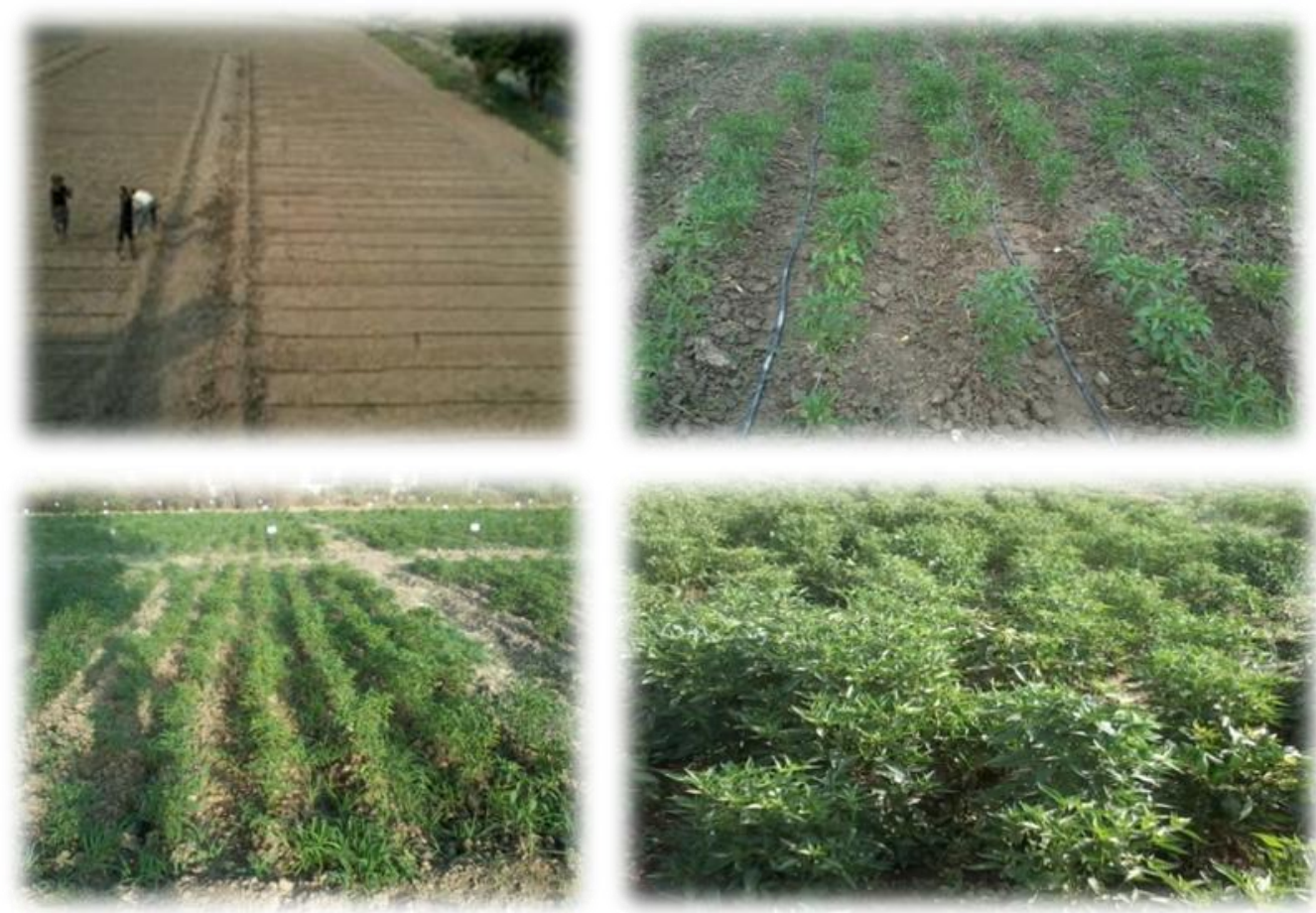

Fig.2 Effect of drip irrigation and fertigation levels on fruit weight and fruit yield

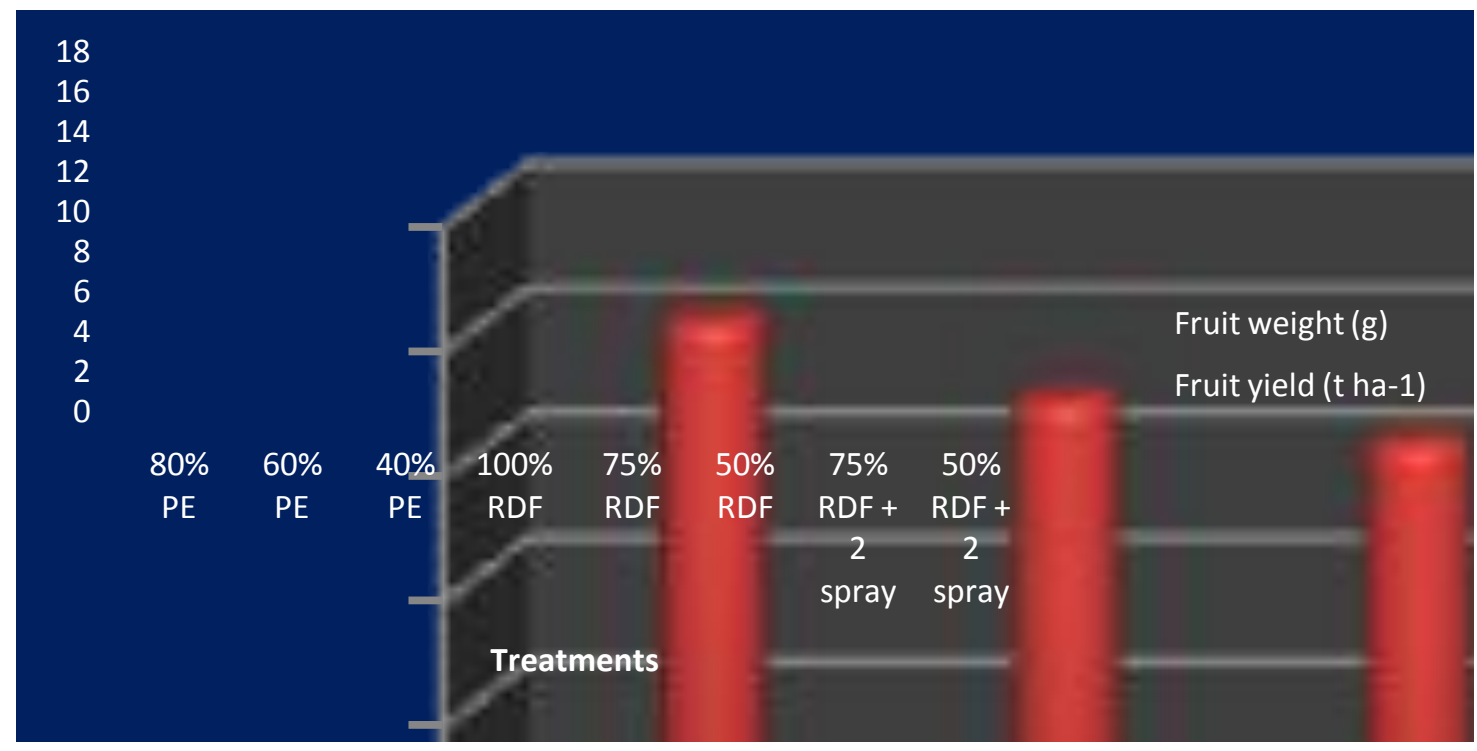


Table.1 Effect of drip irrigation and fertigation levels on fruit weight, fruit yield, Net returns,

$\mathrm{B}$ : $\mathrm{C}$ ratio and water use efficiency of chill

\begin{tabular}{|c|c|c|c|c|c|c|c|c|c|c|c|c|c|c|c|}
\hline \multirow[t]{2}{*}{ Treatments } & \multicolumn{3}{|c|}{ Fruit weight (g) } & \multicolumn{3}{|c|}{ Fruit yield $\left(\mathrm{t} \mathrm{ha}^{-1}\right)$} & \multicolumn{3}{|c|}{ Net returns (Rs. ha $\left.{ }^{-1}\right)$} & \multicolumn{3}{|c|}{ B:C ratio } & \multicolumn{3}{|c|}{ WUE $\left(q\right.$ ha $\left.^{-1} \mathrm{~cm}\right)$} \\
\hline & 2013-14 & 2014-15 & Pooled & 2013-14 & 2014-15 & Pooled & 2013-14 & 2014-15 & Pooled & 2013-14 & 2014-15 & Pooled & 2013-14 & 2014-15 & Pooled \\
\hline \multicolumn{16}{|l|}{ Irrigation levels } \\
\hline Drip at $80 \% \mathrm{PE}$ & 3.29 & 4.17 & 3.73 & 15.74 & 16.53 & 16.14 & 221997 & 238584 & 230291 & 2.05 & 2.19 & 2.12 & 2.59 & 1.97 & 2.28 \\
\hline Drip at $60 \% \mathrm{PE}$ & 3.07 & 3.96 & 3.51 & 14.50 & 15.23 & 14.87 & 198359 & 213665 & 206012 & 1.87 & 2.01 & 1.94 & 3.25 & 2.54 & 2.89 \\
\hline Drip at $40 \% \mathrm{PE}$ & 2.74 & 3.63 & 3.18 & 13.77 & 14.63 & 14.20 & 185294 & 203477 & 194386 & 1.78 & 1.96 & 1.87 & 4.68 & 3.68 & 4.18 \\
\hline $\mathrm{SEm} \pm$ & 0.066 & 0.086 & 0.054 & 3.680 & 3.35 & 2.487 & 7729 & 7028 & 5223 & 0.072 & 0.065 & 0.048 & 0.085 & 0.046 & 0.048 \\
\hline CD $(P=0.05)$ & 0.184 & 0.239 & 0.125 & 10.218 & 9.290 & 5.735 & 21459 & 19512 & 12044 & 0.199 & 0.181 & 0.112 & 0.237 & 0.127 & 0.112 \\
\hline \multicolumn{16}{|l|}{ Fertigation levels } \\
\hline $100 \% \mathrm{RDF}$ & 3.20 & 4.08 & 3.64 & 15.28 & 15.94 & 15.58 & 206881 & 222126 & 214503 & 1.84 & 1.97 & 1.91 & 3.64 & 2.78 & 3.21 \\
\hline $75 \% \mathrm{RDF}$ & 3.02 & 3.91 & 3.46 & 14.72 & 15.44 & 15.08 & 201750 & 217073 & 209411 & 1.88 & 2.02 & 1.95 & 3.55 & 2.73 & 3.14 \\
\hline $50 \% \mathrm{RDF}$ & 2.76 & 3.65 & 3.20 & 13.67 & 14.63 & 14.4 & 184864 & 205563 & 195213 & 1.81 & 2.02 & 1.92 & 3.23 & 2.61 & 2.92 \\
\hline $\begin{array}{l}75 \% \text { RDF + } 2 \text { foliar } \\
\text { spray }\end{array}$ & 3.28 & 4.17 & 3.72 & 15.50 & 16.39 & 15.94 & 217852 & 236724 & 227288 & 2.03 & 2.20 & 2.11 & 3.70 & 2.82 & 3.26 \\
\hline $\begin{array}{l}50 \% \text { RDF }+2 \text { foliar } \\
\text { spray }\end{array}$ & 2.90 & 3.79 & 3.34 & 14.30 & 14.93 & 14.61 & 198069 & 211393 & 204731 & 1.94 & 2.07 & 2.00 & 3.41 & 2.71 & 3.06 \\
\hline $\mathrm{SEm} \pm$ & 0.067 & 0.069 & 0.048 & 2.198 & 2.178 & 1.547 & 4616 & 4574 & 3249 & 0.043 & 0.043 & 0.030 & 0.066 & 0.051 & 0.042 \\
\hline $\mathrm{CD}(\mathrm{P}=\mathbf{0 . 0 5})$ & 0.139 & 0.143 & 0.097 & 4.537 & 4.496 & 3.111 & 9527 & 9440 & 6533 & 0.089 & 0.089 & 0.061 & 0.137 & 0.104 & 0.084 \\
\hline
\end{tabular}

Table.2 Effect of drip irrigation and fertigation levels on total N, P and K uptake after harvest of chilli

\begin{tabular}{|c|c|c|c|c|c|c|c|c|c|}
\hline \multirow[t]{2}{*}{ Treatments } & \multicolumn{3}{|c|}{ Total N uptake $\left(\mathrm{Kg} \mathrm{ha}^{-1}\right)$} & \multicolumn{3}{|c|}{ Total P uptake $\left(\mathrm{Kg} \mathrm{ha}^{-1}\right)$} & \multicolumn{3}{|c|}{ Total K uptake (Kg ha $\left.{ }^{-1}\right)$} \\
\hline & $2013-14$ & 2014-15 & Pooled & 2013-14 & 2014-15 & Pooled & 2013-14 & 2014-15 & Pooled \\
\hline \multicolumn{10}{|l|}{ Irrigation levels } \\
\hline Drip at $80 \% \mathrm{PE}$ & 91.21 & 98.62 & 94.91 & 18.50 & 21.72 & 20.11 & 135.03 & 145.54 & 140.29 \\
\hline Drip at $60 \% \mathrm{PE}$ & 81.24 & 88.03 & 84.63 & 15.83 & 18.39 & 17.11 & 120.53 & 130.32 & 125.43 \\
\hline Drip at $40 \% \mathrm{PE}$ & 75.77 & 82.54 & 79.15 & 13.62 & 15.72 & 14.67 & 110.67 & 121.95 & 116.31 \\
\hline $\mathrm{SEm} \pm$ & 2.274 & 2.03 & 1.525 & 0.540 & 0.49 & 0.363 & 3.247 & 3.39 & 2.345 \\
\hline $\mathrm{CD}(\mathrm{P}=\mathbf{0 . 0 5})$ & 6.313 & 5.64 & 3.517 & 1.498 & 1.35 & 0.838 & 9.016 & 9.40 & 5.409 \\
\hline \multicolumn{10}{|l|}{ Fertigation levels } \\
\hline $100 \% \mathrm{RDF}$ & 88.16 & 95.92 & 92.04 & 17.98 & 20.44 & 19.21 & 131.37 & 141.13 & 136.25 \\
\hline $75 \% \mathrm{RDF}$ & 82.47 & 89.22 & 85.85 & 15.49 & 18.51 & 17.00 & 123.48 & 131.54 & 127.51 \\
\hline $75 \% \mathrm{RDF}+2$ foliar spray & 89.68 & 98.04 & 93.86 & 17.98 & 20.90 & 19.44 & 133.07 & 144.95 & 139.01 \\
\hline $50 \% \mathrm{RDF}$ & 74.24 & 81.06 & 77.65 & 13.68 & 16.07 & 14.87 & 107.78 & 120.70 & 114.24 \\
\hline $50 \% \mathrm{RDF}+2$ foliar spray & 79.13 & 84.42 & 81.78 & 14.77 & 17.13 & 15.95 & 114.68 & 124.71 & 119.69 \\
\hline $\mathrm{SEm} \pm$ & 1.412 & 1.8979 & 1.183 & 0.309 & 0.3493 & 0.233 & 2.232 & 2.0963 & 1.531 \\
\hline $\mathrm{CD}(\mathrm{P}=\mathbf{0 . 0 5})$ & 2.915 & 3.9171 & 2.378 & 0.638 & 0.7209 & 0.469 & 4.607 & 4.3266 & 3.078 \\
\hline
\end{tabular}


Data further revealed that the fertigation had significantly increased nitrogen $\left(93.86 \mathrm{~kg} \mathrm{ha}^{-1}\right)$, phosphorus (19.44 $\mathrm{kg} \mathrm{ha}^{-1}$ ) and potassium $\left(139.01 \mathrm{~kg} \mathrm{ha}^{-1}\right)$ uptake in chilli were registered with $75 \%$ RDF through fertigation +2 foliar spray of $1 \%$ urea phosphate (Table 2). However, different between fertigation with $75 \% \mathrm{RDF}+2$ foliar spray of $1 \%$ urea phosphate and $100 \%$ RDF were found at par. Highest uptake of nitrogen, phosphorus and potassium with increasing fertigation level might be due to the fact that nitrogen increases the cation exchange capacity of plant roots and these make them more efficient in absorbing other nutrient ions like phosphorus and potassium. Higher nitrogen uptake at higher fertigation level was due to increased availability of nitrogen in soil with higher rate of application (Shinde et al., 2006, Kumar and Sahu 2013 and Kohire and Das 2015).

\section{Water use efficiency}

Water use efficiency of chilli was increased significantly with decreasing level of drip irrigation (Table 3). Data on pooled basis showed that the highest water use efficiency $\left(4.18 \mathrm{q} \mathrm{ha}^{-1} \mathrm{~cm}\right)$ was recorded with application of drip irrigation at $40 \% \mathrm{PE}$ followed by 2.89 $\mathrm{q} \mathrm{ha} \mathrm{h}^{-1} \mathrm{~cm}$ at $60 \% \mathrm{PE}$ which resulted in significant increase of 83.33 and 26.75 per cent water use efficiency of chilli over drip irrigation at $80 \% \mathrm{PE}$. Since the rate of water losses through evaporation, percolation and leaching was much lower under drip irrigation, hence water use efficiency was found under lower levels of drip irrigation as compared to higher level of drip irrigation. These results are in agreement with the earlier findings of Thompson et al., (2000) and Gupta et al., (2010).

Maximum water use efficiency was obtained under $75 \%$ RDF through fertigation +2 foliar spray of $1 \%$ urea phosphate by $\left(3.26 \mathrm{q} \mathrm{ha}^{-1}\right.$ $\mathrm{cm})$ and minimum $\left(2.92 \mathrm{q} \mathrm{ha}^{-1} \mathrm{~cm}\right)$ with $50 \%$ RDF fertigation (Table 3). These attributes were found significantly higher with $75 \%$ $\mathrm{RDF}+2$ foliar spray of urea phasphate may be efficiently utilized water and fertilizer for getting higher yield. Water use efficiency was higher under drier regimes and higher fertigation levels and maximum water use efficiency was observed at $75 \% \mathrm{RDF}+2$ foliar spray of urea phasphate $\left(3.26 \mathrm{q} \mathrm{ha}^{-1}\right.$ $\mathrm{cm})$. The present findings are in good accordance with the results of Singandhupe $e t$ al., (2003), Ramachandrappa et al., (2010) and Kapoor et al., (2014).

\section{Economics}

Data revealed that net return and $\mathrm{B}$ : $\mathrm{C}$ ratio increased significantly with the increase level of drip irrigation (Table 3). Highest net returns (230291 Rs. ha ${ }^{-1}$ ) and B:C ratio (2.12) were recorded with application of drip irrigation at $80 \%$ PE. Maximum net return (227288 Rs. ha ${ }^{-1}$ ) and B: C ratio (2.11) were observed with $75 \%$ RDF through fertigation +2 foliar spray of $1 \%$ urea phosphate compared to other treatments. This might be due to the fact that under these treatments the cost of input added was low as compared to output obtained, therefore, higher fruit yields resulted in higher net returns and $\mathrm{B}$ : $\mathrm{C}$ ratio. These findings are similar to those Muralikrishnasamy et al., 2006 and Vijayakumar et al., 2010.

From the above mention result emanated from present investigation conducted during summer season 2013-14 and 2014-15 it can be concluded that the higher yield and nutrient uptake of chilli can be achieved by drip irrigation at $80 \% \mathrm{PE}$ along with $75 \% \mathrm{RDF}$ through fertigation +2 foliar spray of $1 \%$ urea phosphate. Water use efficiency increased under $40 \%$ PE drip irrigation along with $75 \%$ RDF through fertigation +2 foliar spray of $1 \%$ urea phosphate. The highest net return 
and benefit cost ratio of chilli was obtained with the combined application of $80 \% \mathrm{PE}$ through drip irrigation $+75 \%$ RDF through fertigation +2 foliar spray of $1 \%$ urea phosphate.

\section{References}

Ayyadurai, P. and P. Manickasundaram, P. 2014. Growth, nutrient uptake and seed cotton yield as influenced by foliar nutrition and drip fertigation in cotton hybrid. International Journal of Agricultural Sciences. 10 (1): 276-279

Gupta A.J., Ahmed, N. and Singh, L. 2010. Response of lettuce to drip irrigation and fertigation. Indian Journal of Fertilizer. 6:12-16.

Gupta, A.J. and Chattoo, M.A. 2014. Response of knolkhol CV. Early White Vienna to drip irrigation and fertigation in Kashmir Region. Indian Journal of Ecology. 41 (1): 152-157.

Hebbar, S.S., Ramachandroppa, B.K., Nanjappa, H.V. and Prabhakar, M. 2004. Studies on NPK drip fertgation in field grown tomato (Lycopersicum esculantum Mill.). European Journal of Agronomy, 21:117-127.

Kadam, U. S., Deshmukh, M. R., Takte, R. L. and Daund, V. P. 2006. Fertigation management in cauliflower. Journal of Maharashtra Agricultural Universities; 31:252-255.

Kapoor, R., Sandal, K. S., Sharma, S. K., Kumar, A. and Saroch, K. 2014. Effect of varying drip irrigation levels and NPK fertigation on soil water dynamics, productivity and water use efficiency of cauliflower (Brassica oleracea var. botrytis) in wet temperate zone of Himachal Pradesh Indian Journal of Soil Conservation.42: (3) : 249-254.

Kohire, V.O.P., and Das, J.C. 2015. Effect of Drip Irrigation and Fertilizer Management on Capsicum (Capsicum
Annum L) Journal of Agriculture and Veterinary Science. 8 (1): 10-13

Kumar, P.and Sahu, R.L. 2013. Effect of irrigation and fertigation levels on Cabbage. An Asian Journal of Soil Science. 8 (2): 270-274.

Muralikrishnaswamy, S., Veerabadran, V., Krishnasamy, V., Kumar, V. and Salthivel, S. 2006. Drip irrigation and fertigation in chillies (Capsicum annum). In: $7^{\text {th }}$ International microirrigation congress, Kaula Lumpur, Malaysia.

Narayanamoorthy, A., 2008. Study on drip fertigation on india: can it solve water scarcity? Water Polciy 6, 117- 130.

Neilsen, G.H., Neilsen, D.L., Herbert, C. and Hogue, E.J. 2004. Response of apple to fertigation of $\mathrm{N}$ and $\mathrm{K}$ under conditions susceptible to the $\mathrm{K}$ deficiency. American Society for Horticultural Science, 6:129: 132.

Ramachandrappa, B.K., Nanjappa, H.V., Soumya, T.M. and Mudalagiriyappa. 2010. Effect of Fertigation with Sources and Levels of Fertilizer on Yield, Quality and Use Efficiency of Water and Fertilizer in Green Chilli (Capsicum annuum L., ). Indian Journal of Dry land Agriculture Research \& Development. 25 (2): 33-39

Sanchez, R; Botia, P.; Sironi, A.; Crespo, P.; Marin, A. and Nartinez, C. 2001. Vegetative growth and nutrient absorption in cauliflower. Investigation Agrarian, Production Y Protection Vegetable, 16(1): 119-130.

Shinde, P.P.; Chavan, M.G. and Newase, V.B. 2006. Studies on fertigation in cabbage. Journal of Maharastra Agriculture University, 31 (3): 255-257.

Singh, R. and Kumar, S. 2007. Effects of drip irrigation and black polyethylene mulch on growth, yield, and water use efficiency and economics of tomato. Vegetable Science 34(2): 177-80. 
Thompson, T.L., Doerge, T.A. and Godin, R.E. 2000. Nitrogen and water interactions in subsurface drip irrigated cauliflower. Soil Science Society of America 64 (1):406-411

Vasu, D. and Reddy, M. S. 2013. Effect of fertigation on yield, quality, nutrient uptake, fertilizer and water use efficiency in (Brassica oleracea). Agropedology 23: (2) 106- 112.

Vegetable Statistics, (2012-13). Indian Institute of Vegetable Research (Indian Council of Agricultural Research)
Varanasi, Uttar Pradesh (India). Vijayakumar, G., Tamilmani, D. and Selvaraj, P.K. 2010. Irrigation and Fertigation Scheduling under Drip Irrigation in Brinjal (Solanumm elongena L.) Crop. Indian Journal of Bio-resource Management, 1: 72-76.

Vzekoslav, T., Ordan, C., Domor, R. and Gabriyel, O. 2011. The influence of drip fertigation on water use efficiency in tomato crop production. Agriculture Conspectus Scientiificus.76: 57-63.

\section{How to cite this article:}

Ajeet Singh, S.K. Sharma, Rahul Chopra, Virendra Singh, R.A. Kaushik, R.S. Rathore and Jain, H.K. 2017. Impact of Drip Fertigation on Yield and Nutrients Uptake by Chilli (Capsicum aпnиuт L.). Int.J.Curr.Microbiol.App.Sci. 6(8): 1409-1416. doi: https://doi.org/10.20546/ijcmas.2017.608.171 